\title{
An Overview of the Paul Claudel Society in America
}

\author{
Part Two: 1972-2001
}

\author{
Louise R. Witherell \\ Professor emerita \\ University of Wisconsin, Green Bay
}

\begin{abstract}
As we have seen, the establishment of the Paul Claudel Society (America) was preceded by the Claudel Newsletter, which was published from April 1968 until February 1972. The editorial committee of that Newsletter then formed the nucleus of a group of university faculty who established the Paul Claudel Society during a meeting at the large Modern Language Association's conference in New York City on December 29, 1968.
\end{abstract}

The most excellent Claudel Newsletter's last issue appeared in February 1972. The first issue of Claudel Studies appeared later that same year of 1972 (with no indication of the month) under two Editors-inChief: Harold A. Waters ... University of Rhode Island and Moses M. Nagy ... University of Dallas. Moses M. Nagy and Robert Dupree, both from the University of Dallas, are listed as Managing Editors. The three Associate Editors are three names from the Newsletter's editorial committee: Calvin Claudel (Salisbury State College); Douglas Alexander (State University of New York at Albany); and Jean-Pierre Cap (Lafayette College).

Claudel Studies Volume I, 1972, Number I was published by its Editorial Board (see above) and sponsored by the University of Dallas, the Cultural Services of the French Embassy, and the Paul Claudel Society in America. The cost per issue, the cost of a subscription for Americans, the cost for foreign subscribers, as well as the cost of a subscription plus a membership in the Paul Claudel Society are all indicated ahead of the table of contents.

I have taken the time to examine each issue until the final volume dated 2001, but since our present concern is with our Society rather 
than with the details of the parallel publication, I leave that close examination to younger scholars.

In any case, it will always seem to me that the RENCONTRES IINTERNATIONALES CLAUDÉLIENNES DE BRANGUES which took place mostly within the grounds of the château at Brangues July 2528 1972, were crucial to the development of our own organization, affecting the focus of much of the scholarly research and activity on our side of the Atlantic. At this first international Claudelian meeting in France, my presence was almost accidental: I was merely a recent pastpresident of the relatively new American society, taking a daughter on a promised trip to Europe. The official delegation from our society to the international conference consisted of officers Leon Bourke, president; Joan Freilich, secretary-treasurer; and Claudel Studies editors Harold Waters and Moses Nagy. Counting all of the "participants", including actors, technicians, and the almost regal military guard accompanying Léopold Sédar Senghor, president of Sénégal, there were approximately 300 Claudelians from around the world at Brangues. My count for the total USA attendance alone is 26; this may hold the record for the largest USA attendance at any Brangues meeting until now. By my reckoning at least 15 of those 26 became very active members of our society over the following years.

The whole 1972 meeting in France was superbly planned with excellent presentations and discussions which spoke to the enthusiasms of the worldwide participants. There were side trips to Hostel and to Morestel, as well as to Côte Saint-André, where there was a concert devoted to the music of Berlioz and Milhaud. Many stage and film actors and actresses devoted to Claudel's work were present besides those involved in the major presentation by the Renaud-Barrault Company: Eve Francis offered a mesmerizing recitation of Claudelian poetry, for example. The delegation from Japan brought a Nô version of Claudel's ballet "La femme et son ombre." The poet Léopold Sédar Senghor gave a fascinating explanation of his poetry and its debt to Claudel. To top it all there was the performance of the quatrième journée of the "Soulier de Satin." If ever the rest of the world could see and hear the power of Claudel's poetic theatre on a stage - live! — or on the central ground here beneath a chapiteau, performed by actors of the highest training in all possible skills, it was here at this time. Jean Louis Barrault, Madeleine Renaud and the rest of the players would take the tent performance on to Paris after leaving Brangues, and eventually it would grow into the 
now famous performances of the hours-long totality of Claudel's "Soulier" - the most recent such lengthy presentation having occurred in April 2003 under director Olivier Py in Strasbourg.

In the "programme" printed for these 1972 performances can be found also reports of various contemporary Claudelian happenings in Canada (Léo Brodeur) and in the United States (Joan Freilich, MarieHélène Pauly, Louise Witherell).

There had been some world-wide celebrations of the centenary of Paul Claudel's birth in 1968. Now the Brangues "rencontres" which celebrated the accessibility of his work through various kinds of performance surely gave a world-wide impetus to trying to bring this beautiful and meaningful work to people of all cultures and all languages. It seems to me that this emphasis on public access to his work deeply impressed our American society members who had witnessed this meeting in 1972. Complete records of what our society did about it are, of course, not neatly assembled. The task of detailed documentation should attract younger scholars: it could be surprising and gratifying to find what has been done in America with the Claudelian oeuvre since our society was formed. Younger American scholars - especially those interested in theatre - should find this an almost endless field for research. They would find compelling reasons to go to France to visit the current year's performances there or perhaps to go to other countries such as Belgium, Germany, the Czech Republic, Russia, or even Japan. References to past performances may be found in brief international listings in the Bulletin de la Société Paul Claudel (France) as well as sporadically at the end of issues of Claudel Studies (1972-2001).

My interest in Claudel's theatre had begun well before 1972 as a result of a request from a theatre colleague (H.L. Zillmer, University of Wisconsin-Fox Valley) to assist him in translation of some of Claudel's plays. In 1966 I had gone to Gallimard in Paris in order to coordinate our efforts within international publishing rights. After 1972, the two of us were far from alone. Not only were some of Claudel's plays being performed by both amateur and professional companies over here in the Americas, sometimes in university theatres, but the Paul Claudel Society in America from then on had frequent live performances of short plays or of excerpts from longer plays during our annual meetings at MLA. Naturally, our society always welcomed also traditional scholarly studies of all of the many varieties of Paul Claudel's work. Sometimes we supplemented the announced program items with panel discussions or 
spontaneous irresistible additions from those present. At times the yearly program might be centred on a special theme. There was no chance for boringly repetitious programs!

As a beginning to studying the contributions of American scholars to Claudelian research charts could be made of our society's programs, their times and places, as well as authors and titles of presentations, actors, etc. Some of the presentations were later published in Claudel Studies, but perhaps not all. A separate complete, categorized listing could be made of the contents of Claudel Studies and Claudel Papers.

Scholars, arise! There is work to be done! It is necessary in order to have a real sense of perspective in regard to our present and future handling of Claudel's work from an American point of view. We need to know about all past achievements, not only our own, but all ancillary events, forums, colloquia, etc., as for example the successful "colloque international:" Paul Claudel: les Odes, arranged by Sergio Villani in October, 1993, in Toronto, Ontario, Canada. And let us not forget to try to include all of the many plays in French or in English translation which took place outside of our organization.

In the late 1970's as a result of the efforts of one of our most active members over many years, Ann Bugliani, professor of French at Loyola University (Chicago), a Claudel archives was established at that university. I was present at the formal establishment and presented, as I remember it, at least one small work of art related to Claudel which had come to me from the hands of Renée Nantet Claudel. In 1983, at least, I passed on some volumes intended for the archives from the French society. Since I began this history, I attempted to find out the present status of the archives at Loyola (Chicago) by phone. They are, of course, still there. But I received the impression that their libraries, like so many parts of our universities have been downsizing. So perhaps this is an area for the present and future development by our society.

Another subject that we might want to discuss in future meetings is the past structure and operation of the American Paul Claudel Society. For the major portion of our existence we tended to elect a new president and slate of officers every year. In the earliest years, continuity was created by re-electing the secretary-treasurer, the most efficient scholarly secretary Joan Freilich, who maintained the records now lost. More recently we have been enjoying a long more stable period as an organization under the committed leadership of such scholar-members as Sergio Villani, Ann Bugliani, and Nina Hellerstein. Forgive me if there 
are other names that should be mentioned as well: I am really out, of the loop these days!

Here and now is surely the moment to catch our breath, to appreciate all that we have done in the past along with our strong work in the present years, and to go on confidently with our well established aims and contributions proudly referred to in the paragraph just preceding this overview of the Paul Claudel Society in America 1968-2001. 